\title{
DUKUNGAN SOSIAL ANAK TUNARUNGU
}

\author{
Dwi Yufi Apriliani Fisalma \\ Fakultas Psikologi \\ Universitas Ahmad Dahlan Yogyakarta \\ dwi1700013132@webmail.uad.ac.id
}

\begin{abstract}
Abstrak
Anak tunarungu membutuhkan dukungan sosial dalam kehidupannya. Tujuan dari penulisan ini untuk menjelaskan dan memberikan gambaran tentang dukungan sosial anak tunarungu. Subjek penelitian ini yaitu anak tunarungu di komunitas "Deaf Art Community (DAC)”,yang terdiri dari 3 subjek. Metode yang dilakukan pada penulisan ini adalah observasi dan wawancara. Berdasarkan hasil observasi dan wawancara diperoleh hasil bahwa anak tunarungu di komunitas DAC ingin membuktikan kepada masyarakat bahwa anak tunarungu bisa berprestasi dan mendapatkan dukungan sosial yang diharapkan dari lingkungan sekitar.
\end{abstract}

Kata kunci : anak cacat, dukungan sosial, tunarungu

\section{PENDAHULUAN}

Anak tunarungu adalah anak yang mengalami gangguan pada pendengaran. Anak yang mengalami kelainan pendengaran akan menanggung konsekuensi yang sangat kompleks. Mereka akan mengalami berbagai hambatan dalam meneliti perkembangannya terutama pada aspek bahasa dan penyesuaian sosial. Gangguan pendengaran yang berdampak menjadi hambatan pula bagi anak tunarungu dalam interaksi sosialnya (Sadjaah, 2005). Tunarungu menurut Somantri (2012) bahwa tunarungu dapat diartikan sebagai suatu keadaan kehilangan pendengaran yang mengakibatkan seseorang tidak dapat menangkap berbagai rangsangan, terutama melalui indera pendengarannya. Batasan pengertian anak tunarungu telah banyak dikemukakan oleh para ahli yang semuanya itu pada dasarnya mengandung pengertian yang sama.

Efendi (2006) mengemukakan bahwa seseorang dikatakan mengalami tunarungu apabila mengalami kerusakan pada organ telinga. Menurut Suryana (1996) tunarungu memiliki hambatan dalam perkembangan bahasa, komunikasi, sosial, dan emosi. Melewati hambatan-hambatan itu seseorang yang mengalamai tunarungu harus bisa berdamai dengan keadaan dan membutuhkan dukungan dengan bentuk dorongan baik secara langsung ataupun tidak langsung dari orang-orang terdekat agar individu yang mengalami tunarungu ini bisa menjadi seperti individu lain pada umumnya. Tentama (2014) menyatakan bahwa dukungan sosial diperlukan sebagai dorongan untuk individu mengendalikan emosi/perasaan (mudah marah, mudah tersinggung, sedih yang berlarut- 
larut), kesulitan untuk berkonsentrasi atau berfikir jernih (melamun saat pelajaran), ketakutan, menyendiri, sering mengalami mimpi buruk dan gangguan tidur.

Dukungan sosial merupakan perasaan nyaman, penghargaan, perhatian atau bantuan yang diperoleh seseorang dari orang lain atau kelompoknya (Sarafino, 1997). Menurut teori Baron dan Byrne (2003) menyatakan bahwa dukungan sosial adalah kenyamanan secara fisik dan psikologis yang diberikan oleh teman/anggota keluarga. Menurut Baron dan Byrne peran dukungan untuk anak tunarungu sangat dibutuhkan baik dukungan orang tua atau guru. Pertama, dukungan orang tua sangat efisien bagi anak upnormal. Karena, orang tua bisa memantau secara langsung. Seperti, bagaimana sikapsikap anak saat dirumah, mana yang seharusnya anak tersebut dapat melakukan hal-hal yang sewajarnya, maka dukungan orang tua sangatlah penting dalam proses mental anak upnormal. Kedua, dukungan guru di sekolah merupakan tempat pembelajaran yang baik. Lingkungan sekolah peran guru terhadap anak upnormal sangat dibutuhkan. Memang guru disekolah khusus anak upnormal harus mengeluarkan tenaga yang eksta. Karena anak upnormal memiliki mental yang berbeda dengan anak pada umumnya. Oleh karena itu, peran guru pada anak upnormal bisa berkembang dengan baik.

"Deaf Art Community (DAC)", merupakan komunitas seni beranggotakan difabel rungu. Komunitas ini terus mengembangkan kreativitas yang dimiliki setiap individu. Kegigihan dalam mempertajam fungsi indra yang lainnya untuk menggantikan kekurangan pada pendengaran. Anak tunarungu sering kali dianggap remeh oleh lingkungan sekitarnya. Mereka ingin membuktikan bahwa mereka bisa beradaptasi dengan dunia dengar agar tidak terjadi salah presepsi. Mereka membutuhkan dukungan dari orang tua, keluarga dan yang lain karena itu menjadi dorongan untuk percaya diri. Hasil penelitian Tentama (2009) mengungkapkan bahwa pentingnya peran orang tua dan guru dalam menangani anak saat ini, orang tua dan guru dapat menjadi dukungan dalam penanganan anak ADHD sebagai penanganan awal seperti memberi reward baik verbal maupun non verbal berupa pujian dan hadiah misalnya, karena perilaku orang tua dan guru akan menjadi penentu perilaku anak ADHD.

Berdasarkan uraian diatas maka penulis akan mencoba membahas mengenai dukungan sosial pada tunarungu di komunitas Deaf Art Community (DAC) Yogyakarta. 


\section{PEMBAHASAN}

Dukungan sosial merujuk kepada tindakan yang orang lain lakukan ketika mereka menyampaikan bantuan. Dukungan sosial didefinisikan sebagai suatu rangkaian dukungan yang berfungsi sebagai pendukung individu yang membutuhkan bantuan. Tentama (2014) menyatakan bahwa dukungan sosial diperlukan sebagai dorongan untuk individu mengendalikan emosi/perasaan (mudah marah, mudah tersinggung, sedih yang berlarut-larut), kesulitan untuk berkonsentrasi atau berfikir jernih (melamun saat pelajaran), ketakutan, menyendiri, sering mengalami mimpi buruk dan gangguan tidur. Tentama (2012) menyatakan bahwa dukungan sosial salah satunya yaitu peran orangtua dalam mendidik anak, orangtua memiliki peranan penting untuk keberhasilan dalam mendidik anak harus didasarkan pada keyakinan bahwa anak dapat disembuhkan. Maka hal yang harus dihindari adalah kecemasan dan ketakutan orangtua terhadap anak yang menderita ADHD.

Menurut Sarafino (2006), ada lima bentuk dukungan sosial, yang pertama adalah dukungan emosional terdiri dari ekspresi seperti perhatian, empati, dan turut prihatin kepada seseorang. Dukungan ini akan menyebabkan penerima dukungan merasa nyaman, tentram kembali, merasa dimiliki dan dicintai ketika dia mengalami stres, memberi bantuan dalam bentuk semangat, kehangatan personal, dan cinta. Kedua adalah dukungan penghargaan adalah dukungan ini ada ketika seseorang memberikan penghargaan positif kepada orang yang sedang stres, dorongan atau persetujuan terhadap ide ataupun perasaan individu, ataupun melakukan perbandingan positif antara individu dengan orang lain. Dukungan ini dapat menyebabkan individu yang menerima dukungan membangun rasa menghargai dirinya, percaya diri, dan merasa bernilai. Dukungan jenis ini akan sangat berguna ketika individu mengalami stres karena tuntutan tugas yang lebih besar daripada kemapuan yang dimilikinya. Ketiga adalah dukungan instrumental merupakan dukungan yang paling sederhana untuk didefinisikan, yaitu dukungan yang berupa bantuan secara langsung dan nyata seperti memberi atau meminjamkan uang atau membantu meringankan tugas orang yang sedang stres. Keempat adalah dukungan informasi dukungan yang berada di sekitar individu akan memberika dukungan informasi dengan cara menyarankan beberapa pilihan tindakan yang dapat dilakukan individu dalam mengatasi masalah yang membuatnya stres, yang terdiri dari nasehat, arahan, saran ataupun peniliain tentang bagaimana individu melakukan sesuatu. Misalnya individu mendapatkan informasi dari dokter tentang bagaimana mencegah 
penyakitnya kambuh lagi. Kelima adalah dukungan kelompok merupakan dukungan yang dapat menyebabkan individu merasa bahwa dirinya merupakan bagian dari suatu kelompok dimana anggota-anggotanya dapat saling berbagi. Misalnya menemani orang yang sedang stres ketika beristirahat atau berekreasi.

Peran dukungan pada komunitas ini sangat penting sesuai dengan penelitian Tentama (2014) bahwa, diharapkan dengan adanya dukungan sosial dari orang tua, guru, teman sebaya, dan lingkungan masyarakat akan menjadikan remaja memiliki kepercayaan diri yang baik, merasa diterima, merasa disayangi, merasa diperhatikan, merasa diakui, dan yang lebih penting merasa mempunyai dapat kembali hidup secara normal. Selain itu juga menurut Tentama (2014) bahwa, semakin tinggi dukungan sosial maka semakin rendah ganguan stres yang dialami; dan sebaliknya, semakin rendah dukungan sosial yang diterima remaja, maka semakin tinggi gangguan stress yang dialami.

Hasil wawancara dengan komunitas tersebut, mereka mencoba menunjukan kepada masyarakat luas bahwa mereka juga bisa berprestasi. Mereka mampu melakukan segalanya, kecuali mendengar melalui telingga. Ada satu hal yang paling berdampak positif adalah dukungan, baik dukungan orang tua, keluarga, dan lingkungan sekitar, Karena, masyarakat meganggap tunarungu itu berbeda. Adanya dukungan yang diberikan maka yang tadinya individu merasa malu, menjadi individu yang percaya diri. Akhirnya muncul rasa keberanian dalam kreativitasnya sendiri.

\section{KESIMPULAN}

Dari pernyataan diatas dapat disimpulkan bahwa anak tunarungu sangat membutuhkan dukungan sosial. Baik itu dukungan dari orang tua, keluarga, lingkungan, dan guru. Karena, pengaruh dari dukungan sosial ini sangat berdampak bagi anak tunarungu. Oleh karena itu, anak tunarungu akan merasa memiliki kepercayaan diri dari dukungan orang-orang tercinta dan akan mengurangi gangguan stress pada anak tunarungu.

\section{DAFTAR PUSTAKA}

Baron. R. A. \& Byrne. D. (2003). Psikologi sosial, edisi kesepuluh jilid 2. Jakarta: Erlangga. 
Efendi, M. Pengantar Psikopedagogik Anak Berkebutuhan Khusus, Jakarta: Bumi Aksara.

Sadjaah, E. (2005). Pendidikan bahasa bagi anak ganguan pendengaran dalamkeluarga. Jakarta: Depdiknas.

Somantri, S. (2012). Psikologi anak luar biasa. Bandung: Revika Aditama.

Sarafino, E. P. (1997). Health psychology. third Edition. New York: John Wiley \& Sons, Inc.

Suryana. (1996) . Keperawatan anak untuk siswa SPK . Jakarta : EGC.

Tentama, F. (2009). Peran orang tua dan guru dalam menangani perilaku hiperaktifitas pada anak ADHD di SLB Negeri 3 Yogyakarta, Kes Mas, 3(1), 51-57.

Tentama, F. (2014). Peran dukungan sosial pada gangguan stres pascatrauma. Republika, 095.

Tentama, F. (2012). Peran orangtua mendidik anak ADHD. Republika, 116.

Tentama, F. (2014). Dukungan sosial dan post-traumatic stress disorder pada remaja penyintas gunung merapi. Jurnal Psikologi Undip, 13 (2), 133-138.

Tentama, F. (2012). Peran guru tentukan pendidikan anak hiperaktif. Suara Merdeka, 74 